\title{
Polak Mały i fantazja impotencji
}

Adam Lipszyc

TEKSTY DRUGIE 2016, NR 6, S. 79-89

DOI: $10.18318 /$ td.2016.6.6

$\mathbf{K}$

ryzys uchodźczy wywołał w Polsce reakcję, w której doszedł do głosu heterogeniczny splot namiętności. Na uwagę zasługuje zwłaszcza jeden z wątków tego splotu, być może nie najbardziej widoczny. W gromkich okrzykach sprzeciwu wobec idei wpuszczenia do Polski choćby garstki potrzebujących oprócz wyrazów godnej ubolewania, lecz przewidywalnej ksenofobii pobrzmiewało także zdumienie, że Unia Europejska w ogóle czegoś od nas żąda. W tym afekcie nie szło już o samych uchodźców, lecz o ideę jakiegokolwiek zobowiązania, które miałoby na nas ciążyć. Jeśli się nie mylę, u podstaw tego zdumienia - które oczywiście natychmiast przeszło w oburzenie - leży pewna zajmująca struktura pamięciowa. W swojej masie polskie społeczeństwo zachowało (i zachowuje) się tak, jakby już kiedyś uiściło pewną opłatę, jakby zrobiło coś lub doznało czegoś, co zwalnia je z wszellkich zobowiązań. Jeśli jednak podmiot przyjmuje postawy, żywi przekonania i podejmuje działania powodowany tego rodzaju fantomowa pamięcia o wydarzeniach niebytych - a zgódźmy się, że w tym wypadku do uiszczenia żadnych „opłat” nigdy nie doszło, że nie
Adam Lipszyc

(ur. 1975) - eseista i tłumacz, pracuje w Instytucie Filozofii i Socjologii PAN, uczy w Szkole Nauk Społecznych, w Collegium Civitas oraz na Uniwersytecie Muri im. Franza Kafki. Ostatnio opublikował książkę Czas wiersza. Paul Celan i teologie literackie (2015). adamlipszyc@gmail. com 
zrobiliśmy nic, co upoważniałoby nas do żywienia tego rodzaju przeświadczeń - to można podejrzewać, że powoduje nim wiązka nieświadomych fantazji na temat samego siebie i jego relacji ze światem. A jeśli tak, to - gdy mamy na uwadze cząstkową choćby diagnozę stanu i mechanizmów polskiej pamięci - warto odwołać się do heterogenicznej tradycji myślowej, która obfituje w narzędzia umożliwiające wydobycie i opis tego rodzaju nieświadomych fantazji. Mam na myśli tradycję psychoanalityczną.

Pośród rozmaitych przegródek w psychoanalitycznej skrzynce pojęciowej proponuję sięgnąć do słownika wypracowanego przez Melanie Klein¹. Jak wiadomo, zasadniczym elementem teorii Klein jest rozróżnienie na dwie „pozycje”. Pozycja to wiązka obron i konkretyzujących je nieświadomych fantazji, która kształtuje się po raz pierwszy we wczesnym niemowlęctwie, następnie zaś powraca na różnych etapach życia podmiotu. Pierwsza z wyróżnionych przez Klein pozycji to pozycja paranoidalno-schizoidalna. Ujmując rzecz w uproszczeniu, można powiedzieć, że w tej pozycji podmiot dzieli świat na wyraziście odróżnione zbiory dobrych i złych obiektów, przy czym nierzadko podwaja pojedynczy obiekt rzeczywisty, rozdzielając go na dobry i zły: w szczególności tak właśnie dzieje się ze źródłowym obiektem, jakim jest pierś matki. Podmiot czuje się prześladowany przez obiekt zły i fantazjuje na temat jego anihilacji, oddając się przy tym snom o własnej, niszczycielskiej omnipotencji. Poczucie wszechmocy pozwala mu też sądzić, że w całości panuje nad wyidealizowanym, dobrym obiektem, z którym w istocie czuje się zjednoczony. Utrata źródłowego obiektu i względna integracja świata (odkrycie, że zła i dobra pierś są jedną i tą samą) powodują, że podmiot przechodzi do pozycji depresyjnej: zamiast lęków prześladowczych dręczą go teraz lęki depresyjne, poczucie winy spowodowane przekonaniem, że to sam podmiot, za sprawą swoich niszczycielskich fantazji, odpowiada za utratę obiektu. Stopniowe, nigdy nieukończone przepracowanie tej pozycji, tzw. reparacja, to proces odbudowywania wiary w istnienie względnie dobrych obiektów, a także rozwój poczucia, że choć jesteśmy za niejedno odpowiedzialni, wszystkiemu winni nie jesteśmy. Ponieważ zaś zarówno sama pozycja depresyjna, jak i proces jej przepracowywania są po prostu bardzo trudne, podmiot raz po raz dokonuje regresji do pozycji paranoidalno-schizoidalnej bądź też popada w manię, w której gwałtownie zaprzecza utracie i świętuje

1 Zob. M. Klein Some Theoretical Conclusions Regarding the Emotional Life of the Infant, w: tejże Envy and Gratitude, Vintage, London 1997, s. 61-93. 
swoją narcystyczną omnipotencję, wszelkie zło i agresję wykluczając z pola widzenia.

Hanna Segal, uczennica Melanie Klein, zaproponowała odniesienie tych kategorii do relacji międzynarodowych². Rozwijając Freudowską koncepcję kultury jako źródła cierpień, Segal stawia prostą, lecz atrakcyjną tezę, że gdy jako jednostki stajemy naprzeciw innych i społeczeństwa jako całości, pozycja depresyjna i związane z nią poczucie odpowiedzialności są na nas poniekąd wymuszane. Gdy jednak występujemy jako grupa - razem, a nie naprzeciw siebie - bolesny system wzajemnej kontroli znika, możemy więc sobie pozwolić na regresję do pozycji paranoidalno-schizoidalnej. Innymi słowy, jako jednostki możemy być mniej lub bardziej dojrzali i odpowiedzialni, jako grupy - w szczególności jako narody - mamy skłonność do paranoi. Jak pisze Segal:

W prywatnym życiu musimy dogadywać się z superego, które kładzie tamę naszej destrukcyjności. Jeżeli powierzymy indywidualne superego połączonemu superego grupowemu [tj.gdy zaczniemy czuć i działać nie jako jednostki, lecz jako członkowie grupy - A.L.], możemy bez poczucia winy uczestniczyć w okropnościach, których nie znieślibyśmy w naszym życiu. Myślę, że na poziomie indywidualnym jedynie psychotycy i psychopatyczni zbrodniarze dokonują takiego odczłowieczenia, z jakim mamy do czynienia w przypadku ludobójstwa. ${ }^{3}$

Albo krócej: „Grupy korzystają z mechanizmów, które zostałyby potraktowane jako psychotyczne, gdyby użyła ich jednostka"4.

Segal pokazuje, jak grupy same się idealizują, osuwają w narcyzm i lęki prześladowcze, zaprzeczają zbrodniczym konsekwencjom swoich czynów, jak wyprojektowują na wrogów zło i agresję, które wyczuwają u siebie, itd. Tę nieskomplikowaną wiązkę pomysłów i spostrzeżeń brytyjska psychoanalityczka odnosi przede wszystkim do zimnowojennej psychozy i charakterystycznej dla owego czasu demonizacji przeciwnika. Co bodaj ciekawsze,

2 Zob. H. Segal Milczenie jest prawdziwa zbrodniq, przeł. D. Golec, oraz Od Hiroszimy po Zatokę Perską i później: społeczno-polityczne wyrazy ambiwalencji, przeł. M. Piskorska, w: tejże Psychoanaliza, literatura i wojna, tłum. różni, Gdańskie Wydawnictwo Psychologiczne, Gdańsk 2005, s. 207-225 i 226-242.

3 Tamże, s. 213-214.

4 Tamże, s. 232. 
Segal stara się też pokazać, w jaki sposób kategorie Kleinowskie pozwalają zrozumieć sytuację międzynarodową po zakończeniu zimnej wojny. Zwraca uwagę, że świat zachodni znalazł się wówczas w szczególnego rodzaju emocjonalnym niebezpieczeństwie. Wobec utraty wyrazistego przeciwnika umożliwiającego utrzymywanie się w pozycji paranoidalno-schizoidalnej groziło mu mianowicie, że będzie musiał przejść w tryb depresyjny i zmierzyć się ze swoją odpowiedzialnością za rozmaite przewinienia, takie jak neokolonializm, katastrofa ekologiczna czy niedofinansowanie kultury czy struktur państwa socjalnego przy jednoczesnych, niedorzecznie wysokich wydatkach na zbrojenia. W interpretacji Segal, unikając tego niebezpieczeństwa, Zachód najpierw popadł w maniakalny stan autocelebry, w którym począł świętować koniec historii i zwycięstwo liberalnej demokracji, następnie zaś z dnia na dzień wymyślił sobie nowego wroga, Saddama Husajna, by odtworzyć pozycję paranoidalno-schizoidalną (jak wiemy, niedługo potem w tym libidinalnym teatrze Saddama Husajna zastąpili kolejni aktorzy).

Oczywiście te konkretne analizy w nader tylko pośredni sposób można odnieść do sytuacji polskiej, pokazują one jednak względną funkcjonalność Kleinowskich kategorii w opisie kondycji zbiorowej. Zachęceni tym przykładem moglibyśmy zatem spróbować zastosować te narzędzia w naszych realiach. Warto wszakże postępować na tym poletku z daleko posuniętą ostrożnością. Jasne jest, że na poziomie znacznej ogólności grupie zwanej narodem polskim można przypisać cechy, które Segal odnajduje we wszystkich zbiorowościach narodowych: narcyzm, psychoza prześladowcza, unikanie poczucia odpowiedzialności, skłonność do zaprzeczania niewygodnym faktom i demonizowania przeciwników. Jest to tyleż słuszne, co banalne. Powinniśmy chyba raczej poluzować nasze kategorie i pozwolić, by mutowały w kontakcie z tym konkretnym przypadkiem, dopiero wówczas bowiem zdołamy może wychwycić specyficzny charakter polskiej sytuacji, w szczególności zaś - polskiej pamięci.

Zauważmy na początek, że Polacy jako zbiorowość (tj. Polacy występujący razem i obok siebie jako Polacy właśnie, a nie jako stające naprzeciw siebie jednostki) nie mają wcale skłonności do maniakalnej euforii. Dowcip, zgodnie z którym także w reakcji na sukces narodowej drużyny piłkarskiej kibice wołają: „Polacy, nic się nie stało”, mówi co nieco na ten temat. Ten brak skłonności do manii widać również w dziedzinie pamięci. Jak wielokrotnie zwracano uwagę, mimo podejmowanych raz po raz wysiłków komemoracyjnych, udane powstanie wielkopolskie nieustannie wylatuje nam z głowy. Święto 4 czerwca, podczas którego na polską skalę moglibyśmy oddawać się 
manii opisywanej przez Segal w odniesieniu do sytuacji Zachodu po zimnej wojnie, od początku wypadało bardzo blado. Główną atrakcją Dnia Flagi był czekoladowy orzeł. A i Dzień Niepodległości miał charakter wysilonego festynu, dopóki nie zawłaszczyli go gniewni narodowcy, którzy - wiecznie wściekli - nie oddają się przecież maniakalnej autocelebrze, lecz buńczucznym ekspresjom resentymentu. Przerysowując obraz gwoli wyrazistości tezy, możemy zatem przyjąć, że nie istnieje coś takiego jak polska mania. Tak jak wszystkie narody, naród polski jest narcystyczny, jego narcyzm nie jest jednak narcyzmem autocelebry.

W następnym kroku należy zatem wysunąć przypuszczenie, że ta specyficzna technika obronna, jaką jest obrona maniakalna, nie występuje w przypadku polskiego pacjenta, ponieważ pacjentowi temu w ogóle nie grozi stan, przed którym owa technika ma go bronić. Tym stanem zaś jest depresja. Innymi słowy, polskiemu pacjentowi nie grozi pozycja depresyjna, poczucie winy i wyrastające z niego - gdy pozycja ta zostanie pomyślnie przepracowana - trzeźwe poczucie odpowiedzialności za własne czyny. Tak więc należy również stwierdzić, że nie istnieje coś takiego jak polska pozycja depresyjna. Nigdy nie byliśmy w tej pozycji, być w niej nie umiemy i nie zanosi się na to, byśmy mieli się tego nauczyć. Jest tak dlatego, że charakterystyczna dla Polski pozycja paranoidalno-schizoidalna jest figurą nader zagmatwaną, która - na ile się orientuję - wykracza poza ramy Kleinowskiej pojęciowości. Jest to pozycja poniekąd niewywrotna, która - inaczej niż „normalna” paranoja - bez jakichś radykalnych przeobrażeń nie może przejść w pozycję depresyjną. Spróbujmy ją opisać.

Otóż wydaje się, że najważniejszą cechą tej pozycji jest dialektyczna odwrotność narcystycznego poczucia wszechmocy, coś, co należałoby określić mianem fantazji impotencji. Byłaby to fantazja o całkowitym braku faktycznych konsekwencji naszych działań, fantazja o całkowitym braku sprawczości. Tego rodzaju konstrukcja wyobrażeniowa jest oczywiście co najmniej tak samo niebezpieczna, jak fantazja omnipotencji: jeśli wydaje mi się, że nic ode mnie nie zależy, że moje działania nie mają rzeczywistych konsekwencji, mogę robić rzeczy straszne i w ogóle tego nie odnotować, a już na pewno nie pamiętać. Bańka złudzeń, w której zamyka nas ta fantazja, ów sen o braku sprawczości, nie jest wszakże czymś przyjemnym. Podmiot oddaje się tej fantazji i czerpie z niej libidinalne korzyści, unika bowiem wszelkiej odpowiedzialności, zarazem jednak uskarża się na swoją kondycję ofiary i swoją zależność od sił zewnętrznych, które nie pozwalają mu wybić się na niepodległość. Pogrąża się więc zarówno w fantazji impotencji, jak i w poczuciu krzywdy. Jest jak mały 
chłopiec, który żali się na swoją zależność od matki; wściekły na własne rozsmakowanie w tej zależności, podejmuje działania buntownicze, by dowieść, że sytuację tę narzucono mu wbrew woli; nie wierzy jednak, by odniosły one jakiś faktyczny skutek, ani też wcale tego nie pragnie; w rezultacie zaś nie zauważa, że przy okazji może zdrowo poturbować innych malców, a i matce może wyrządzić krzywdę.

Sądzę, że taki właśnie splot psychiczny cechuje polską zbiorowość narodową w jej obecnej kondycji. Ponieważ przez dwieście lat, z małą przerwą, zbiorowość ta rzeczywiście pozbawiona była suwerenności i sprawstwa na arenie międzynarodowej, rzeczywiście doznawała rozmaitych krzywd ze strony międzynarodowych potęg, dokonała absolutyzacji tej kondycji i wysnuła z niej spójną fantazję impotencji odgradzającą ją od rzeczywistych skutków własnych działań i odpowiedzialności za owe działania. W ten sposób czerpała i nadal czerpie libidinalny zysk ze swojej pozycji ofiary, względnie swojej pozycji zależności. Samo to uzależnienie od zależności bardzo jej wszakże doskwiera - żaden narcyz nie może przyznać się do takich przyjemności - musi więc wykonywać szereg ruchów pozorowanych. Kiedy więc Prezes Państwa wygłasza dumne mowy, a jego wyborca go słucha, wiąże ich szczególne porozumienie. Na poziomie jawnego przekazu nadawca podkreśla potrzebę odzyskania narodowej dumy, a odbiorca temu przyklaskuje. Na poziomie przekazu niejawnego, nieświadomego dla odbiorcy (co do nadawcy nie śmiem stawiać diagnoz), mówi się tu jednak, że - spokojnie! - i tak się nic nie stanie, bo przecież pozbawieni jesteśmy sprawczości. A jeśli stanie się coś złego, to i tak nawet nie zauważymy związku między naszymi działaniami a wydarzeniami w świecie rzeczywistym. Pozory buty są jednak niezbędne, dowodzą bowiem, że próbowaliśmy się wyzwolić z zależności, a że się nie udało, to już nie nasza wina, tylko smutny los Małego Polaka.

Ta sytuacja ma bezpośrednie konsekwencje dla tego, co i jak pamiętamy, przede wszystkim zaś dla tego, czego nie pamiętamy. Po pierwsze zatem, nie pamiętamy krzywd, które wyrządziliśmy innym grupom etnicznym. To wydaje się całkiem oczywiste: nikt nie lubi pamiętać, że zrobił komuś krzywdę. Jeśli jednak mam rację, polskie niepamiętanie tego rodzaju przewin rządzi się specyficznym mechanizmem, spowodowane jest bowiem fantazją impotencji. Nie mogliśmy nikomu wyrządzić krzywdy, bo przecież my - zawsze bici, zawsze zależni, zawsze pozbawieni autonomii - w ogóle nic nie możemy zrobić. Z tym wiąże się zresztą bodaj ciekawsza okoliczność, że również katastrof, które ściągnęliśmy na własne głowy, nie pamiętamy jako skutków swoich działań. Masakra warszawskiej ludności cywilnej podczas powstania 
warszawskiego - wspominana i tak wybiórczo, najlepiej bez wzmianki o mniej fotogenicznych katastrofach, takich jak masowe gwałty na ochockim „Zieleniaku” - nie jest raczej pamiętana jako rezultat zbrodniczej bezmyślności dowódców powstania, lecz jako efekt działań wojsk niemieckich i cynicznej bezczynności Armii Czerwonej ${ }^{5}$. Po drugie, nader szybko wypada nam z pamięci nasz faktyczny, nie zawsze wymuszony współudział w procesach i wydarzeniach dziejowych faktycznie narzuconych przez zewnętrznych aktorów: znów, mocą fantazji impotencji, przypisujemy je wyłącznie obcym siłom. Być może na tym również polega „prześniony” charakter znacznej części najnowszej historii Polski: nie tylko na tym, że inni robili za nas coś, co odpowiadało naszym ukrytym pragnieniom, byliśmy więc transpasywnymi podmiotami wydarzeń, lecz także na tym, że czasem rzeczywiście współuczestniczyliśmy w tych wydarzeniach, a jednak pamiętamy je tak, jakby działy się poza namí.

Jak jednak odnieść ten splot psychiczny do zarysowanej wyżej pojęciowości Kleinowskiej? Na czym polega specyfika polskiej pozycji paranoidalno-schizoidalnej? Czy w ogóle jest to jeszcze tego rodzaju pozycja? Jak pamiętamy, w standardowej pozycji paranoidalno-schizoidalnej manichejsko usposobiony podmiot rozdziela źródłowy obiekt (pierś matki) na idealizowany obiekt dobry i oczerniany obiekt zły. To rozdzielenie porządkuje jego rzeczywistość i gospodarstwo libidinalne, umożliwia też jednak późniejszą syntezę, która - odsłaniając winę podmiotu wobec scalonego obiektu skutkuje pozycją depresyjną. W przypadku polskiej pozycji paranoidalno-schizoidalnej sprawa wydaje się bardziej skomplikowana. W jej zrozumieniu dopomóc mogą kategorie wypracowane przez Waltera Benjamina w jego rozważaniach nad mitem?

Dla Benjamina mit był opresyjną strukturą historiozoficzną, do której naczelnych cech należy coś, co autor Pasaży określał mianem demonicznej dwuznaczności. Mit jest dwuznaczny, ponieważ w ramach struktur mitycznych

5 W pierwszych dniach sierpnia 1944 roku dzielni powstańcy wycofali się z Ochoty, pozostawiając ludność cywilną na pastwę oddziałów RONA. Na terenie targu "Zieleniak" utworzono obóz przejściowy, a w pobliskiej szkole dokonywano masowych gwałtów. Zob. L. Hering Zieleniak, w: tegoż Ślady, Czarna Owca, Warszawa 2011, s. 7-17; S. Chutnik Kieszonkowy atlas kobiet, Ha!art, Kraków 2008, s. 79-136.

6 Zob. A. Leder Prześniona rewolucja. Ćwiczenie z logiki historycznej, Wydawnictwo Krytyki Politycznej, Warszawa 2014.

7 Zob. W. Benjamin Los i charakter oraz Przyczynek do krytyki przemocy, przeł. A. Lipszyc, w: tegoż Konstelacje, przeł. A. Lipszyc, A. Wołkowicz, Wydawnictwo UJ, Kraków 2012, s. 61-68 i 69-94. 
wszelkie przeciwieństwa - takie jak wolność i zniewolenie, równość i hierarchia, czystość i grzeszność - wzajemnie w siebie przechodzą. Otóż sądzę, że polska pozycja paranoidalno-schizoidalna to pozycja demonicznie dwuznaczna w tym sensie, że w pozycji tej zamiast manichejskiego rozdzielenia dobrego i złego obiektu dochodzi do ich dwuznacznego pomieszania. Należy to podkreślić: do dwuznacznego pomieszania, nie zaś do charakterystycznego dla pozycji depresyjnej scalenia, w wyniku którego obiekt jawi się nam jako trochę dobry, a trochę zły. Owo dwuznaczne pomieszanie polega na tym, że dla podmiotu istnieje tylko jeden i ten sam obiekt, ów jednak jawi się jako dobry i zły zarazem. Ściśle rzecz biorąc, jest on dobry dlatego, że jest zły, a zły dlatego, ze jest dobry. Obiekt ów jest zły: jest prześladującym nas opresorem; dlatego, że jest zły, jest też jednak dobry, ponieważ pozwala nam utrzymać się w stanie zależności, dzięki której możemy oddawać się wygodnej fantazji impotencji, unikać wszelkiej odpowiedzialności za własne czyny, nie pamiętać, że cokolwiek faktycznie zrobiliśmy (w szczególności: że wyrządziliśmy komuś krzywdę). Obiekt ów jest dobry: jest wspierającą nas siłą zewnątrzną, mocarstwem lub imperium; dlatego, że jest dobry, jest też jednak zły, ponieważ naszą wygodną zależność od niego odczuwamy zarazem jako opresję i krzywdę, jako naruszenie naszej narcystycznej podmiotowości. Stąd też zresztą nie jesteśmy w stanie idealizować dobrego obiektu, choć wcale nie dlatego, że postrzegamy go trzeźwo: ponieważ musimy sobie uzasadnić nasze własne pretensje wobec niego, obiekt ten nigdy nie wydaje nam się dość dobry, dość pomocny, dość opiekuńczy, stąd też zawsze jawi nam się ostatecznie jako obojętny, zdradziecki, a wreszcie po prostu zły. W opisywanej przez Benjamina strukturze mitycznej zniewolony podmiot ma akurat tyle autonomii, by można go było obarczyć winą. W demonicznie dwuznacznej pozycji paranoidalno-schizoidalnej podmiot ma akurat tyle autonomii, by uskarżać się, że nie ma jej więcej - choć zarazem więcej mieć jej nie chce, wówczas bowiem musiałby zrezygnować ze swojej fantazji impotencji.

Sądzę, że taki sposób postawienia sprawy pozwala wyjaśnić niewielką zagadkę fantomowej pamięci o rzeczach niebyłych, która - jak widzieliśmy na początku - doszła do głosu w polskich reakcjach na kryzys uchodźczy. Nieświadoma fantazja, która przynajmniej po części odpowiada za wywołanie tych reakcji, miała - jak sądzę - strukturę następującą. Z polskiego (nieświadomego) punktu widzenia Unia Europejska jest libidinalną spadkobierczynią wszystkich wielkich obiektów, które wyrządzały nam krzywdę i/lub od których pozostawaliśmy zależni. Libidinalnie jest tożsama nie tylko z tzw. obojętnym Zachodem, lecz także z wszystkimi rozbiorcami i najeźdźcami. 
Za wszystkie krzywdy, których zaznaliśmy od tego jednolitego-acz-dwuznacznego obiektu, należą nam się reparacje. Mówiąc o reparacjach, nie mam oczywiście na myśli procesu przepracowywania pozycji depresyjnej, które jest procesem zdrowienia; mam na myśli odszkodowanie za krzywdy. Dotacje unijne są tego rodzaju reparacjami. A jeśli tak, to fakt ich uzyskania nie nakłada na nas żadnych zobowiązań, ponieważ to one stanowią należytą odpłatę za coś, co spotkało nas wcześniej. Ale to nie wszystko. Jeśli bowiem mam rację, obraża nas sam fakt uzyskiwania owych dotacji: obiekt jest zły dlatego, że jest dobry. W Benjaminowskim świecie mitu obarczony winą podmiot składa ofiarę, mając na uwadze oczyszczenie, by zaraz jednak przekonać się, że mechanizm ofiarniczy perpetuuje władzę mitycznej opresji. Także w tym wypadku polska pozycja paranoidalno-schizoidalna okazuje się dialektycznym rewersem Benjaminowskiej konstrukcji: tutaj podmiot domaga się reparacji za krzywdy, otrzymuje je, lecz samo otrzymanie reparacji traktuje jako akt napaści i naruszenia autonomii, oczekuje więc ponownej transzy odszkodowań. Jak w dowcipie, który słyszałem pod Warszawą: „Za co Unia powinna nam płacić? Za to, że płaci".

Gdyby nakreślony obraz dokładnie odpowiadał rzeczywistości, nie byłoby dla nas nadziei. Demoniczna wersja pozycji paranoidalno-schizoidalnej nie może ustąpić miejsca pozycji depresyjnej: nie może dojść do scalenia dobrego i złego obiektu, te bowiem już trwają w dwuznacznym pomieszaniu, tworząc iście demoniczną figurę obiektu dobrozłego, od którego pozostajemy zależni. Ponieważ obiekt ten jest dobry, bo jest zły, a zły, bo jest dobry, konstrukcja ta jest po prostu niewywrotna. Oznaczałoby to, że w postaci Polaka Małego udało się wyprodukować doskonałego narcyza resentymentu, który mości się w swojej krzywdzie i który, oddając się fantazji impotencji, nie dba o żadną odpowiedzialność. Konfrontowanie go ze skutkami jego obecnych i dawniejszych uczynków mija się z celem, ponieważ fantazja ta pozwala mu zaprzeczać, by dana mu była jakakolwiek sprawczość.

Na szczęście jednak rzeczywistość jest o wiele bardziej chropawa i wielowymiarowa niż tego rodzaju przerysowane wizerunki. Właśnie ta chropawość i wielowymiarowość otwiera szansę na przełamanie tej demonicznej sytuacji. Co najmniej dwie kwestie zasługują w tym względzie na uwagę. Po pierwsze, nawet jeśli prawdą jest, że jako Polacy zachowujemy się inaczej niż jako jednostki, że stając obok siebie, a nie naprzeciw siebie, mamy skłonność do regresji do demonicznej pozycji paranoidalno-schizoidalnej, to nie należy zapominać, że byty zbiorowe po prostu nie istnieją, tak więc każdy z nas nieco inaczej odgrywa ten zbiorowy program. Dlatego nie jest prawdą, że 
uporczywe konfrontowanie nas z tymi aspektami polskiej historii, które za sprawą fantazji impotencji wyleciały nam z głowy (bądź też nigdy nie zostały dostrzeżone), skazane jest na całkowite niepowodzenie. Nawet jeśli u wielu wywołuje reakcję obronną, ten i ów - ta i owa - zmienia się pod wpływem takiej konfrontacji. Po drugie, zwrócono mi uwagę, że model, który kreśliłem powyżej, może być (przerysowanym) wizerunkiem „pozycji” charakterystycznej nie tyle dla całej Polski, ile dla Warszawy czy terenów byłej Kongresówki. To z pewnością prawda, choć prawdą jest też, że za pośrednictwem mediów, szkolnych programów nauczania i propagandy politycznej Warszawa kolonizuje Polskę, wszechobecność owej pozycji pozostaje więc faktem. A jednak inne narracje pamięciowe nie przestały istnieć i mogą posłużyć do rozszczelnienia pozornie monolitycznej, demonicznej pozycji paranoidalno-schizoidalnej i charakterystycznego dla niej sposobu pamiętania opartego na fantazji impotencji. Być może kiedyś, konfrontowana z zapomnianymi ścieżkami i alternatywnymi narracjami, pozycja ta ulegnie deregulacji i otworzy nam drogę do pozycji depresyjnej, którą później będziemy jeszcze musieli nauczyć się przepracowywać. Na razie jednak nie wygląda na to, byśmy w najbliższym czasie mieli zabrać się za tę trudną robotę. Polak Mały nazbyt chętnie trwa przy swej fantazji impotencji. 


\section{Abstract}

\section{Adam Lipszyc}

INSTITUTE OF PHILOSOPHY AND SOCIOLOGY OFTHE POLISH ACADEMY OF SCIENCES

The Little Pole and the Fantasy of Impotence

Lipszyc analyses Polish collective memory from a psychoanalytical perspective. Building on the work of Melanie Klein and its application to international relations as proposed by Hanna Segal, he tries to show that the Polish collective subject and the memory that defines it exist in a particular form of the paranoid-schizoid position. The defining characteristic of this position is a fantasy of one's own impotence, which allows the subject to disregard his or her own agency and to eschew responsibility for his or her own actions. Lipszyc enhances his analysis by drawing on Walter Benjamin's notions on myth and the demonic.

\section{Keywords}

paranoid-schizoid position, fantasy of impotence, myth, demonism, memory 